ljtihad, Jurnal Wacana Hukum Islam dan Kemanusiaan

Vol. 17, No. 2 (2017), pp. 155-174, doi : 10.18326/iitihad.v17i2.155-174

\title{
Poligami menurut Nasr Hamid Abu Zayd: studi atas pengaruh pemikiran tafsir terhadap penetapan hukum
}

\author{
Cucu Surahman \\ Program Studi Ilmu Pendidikan Agama Islam (IPAI) UPI Bandung \\ E-mail:cucu.surahman@upi.edu
}

DOI: 10.18326/ijtihad.v17i2.155-174

This article examines Nasr Abu Zayd's (d. 2010) thought of tafsir and takes a close look at its implementation when he interprets "polygamy verses". With library research method and content analysis, I conclude that Abu Zayd uses thematic method of interpretation, by using contextual analysis approach. This method is similar to Fazlur Rahman's Double Movement method. Abu Zayd's contextual interpretation theory (al-qiräa'ah al-siyäqiyyab) operates in the following steps; first, turn to the meaning (ma'nā) of the text in its historical and cultural context (tarikbiyyat al-dalalab); and second, implement its significance (maghzā) in contemporary context. Based on his contextual analysis (al-qirāa ab al-siyāqiyyah) to polygamy verses, Abu Zayd concludes that polygamy is not the final purpose Islamic teaching (shari'ah al-Islamiyah). Polygamy is a temporal decision which is related to the very tight prerequisites. According to him, the significance (maghza $\bar{a}$ ) of the Qur'an text talking about polygamy is however justice and equality. Otherwise, Abu Zayd says that the implicit (maskét 'anhu) final purpose of the revelation of "polygamy related-verses" are monogamy.

Tulisan ini akan mengkajii pemikiran tafsir Nasr Abu Zayd (w. 2010) dan melihat penerapan metode tafsirnya ketika ia menjelaskan "ayat-ayat poligami." Dengan metode riset kepustakaan (library research) dan analisis isi (content analysis), penulis berkesimpulan bahwa Abû Zayd menggunakan metode tafsir tematik, dengan pendekatan (analisis) kontekstual. Metodenya ini mirip dengan metode Double Movement Fazlur Rahman. Adapun teori penafsiran kontekstual (al-qiräah al-siyäqiyyah) Abu Zayd adalah sebagai berikut, pertama, kembali pada makna (ma'nā) dalam konteks historis dan kultural teks (tärikhiyyat al-dalälab); dan kedua, menerapkan makna signifikansi (maghzāa) dalam konteks kontemporer. Berdasarkan analisis kontekstual (al-qirāah al-siyäqiyyah)-nya atas "ayat-ayat poligami," Abu Zayd berkesimpulan bahwa poligami bukanlah tujuan (akhir) dari syariat Islam. Poligami adalah ketetapan temporal yang terkait persyaratan-persyaratan yang sangat ketat. Adapun signifikansi (maghža $\bar{a}$ ) teks al-Qur'an yang berbicara tentang poligami menurutnya justru adalah keadilan dan kesetaraan. Abu Zayd kemudian 
mengatakan bahwa tujuan akhir tersirat (maskūt 'anhu) dari pewahyuan "ayat-ayat poligami” tersebut adalah monogami.

Keywords: Abu Zayd; Contextual exegesis; Polygamy

\section{Pendahuluan}

Tampaknya tidak ada satu orang pun yang menolak bahwa al-Qur'an memiliki posisi yang sangat sentral di dunia Islam. Karena posisinya itu, seperti dikatakan Hasan Hanafi, al-Qur'an telah berperan sebagai inspirator dan pemandu gerak dan dinamika umat Islam sejak kurang lebih empat belas abad yang lalu (Hanafi, 1989: 7). Oleh karena itu, ketika melihat ada sesuatu yang dirasa janggal dalam realitas umat Islam, termasuk dalam hal relasi laki-laki dan perempuan, maka banyak sarjana yang kemudian meniliknya dalam al-Qur'an. Pertanyaan yang biasa terlontar adalah: apakah benar al-Qur'an melegitimasi bahwa laki-laki lebih tinggi derajatnya dibanding perempuan?, Apakah benar al-Qur'an memandang perempuan hanya setengah dari laki-laki (misalnya dalam hal kesaksian dan pembagaian harta warisan)?, Benarkah al-Qur'an memerintahkan untuk mempraktekkan poligami?; Apa yang al-Qur'an katakan tentang semua itu?

Dan ketika melihat ada sesuatu yang janggal dalam keterangan al-Qur'an, para sarjana Muslim mencoba menafsir ulang (to reinterpret) dan berkesimpulan bahwa kejanggalan tersebut terjadi karena kesalahan penafsiran (miss-interpretation). Misalnya terkait relasi laki-laki dan perempuan tersebut, Nina Nurmila, dalam bukunya Women, Islam and Everyday Life, meyakini bahwa sumber dari ketidaksetaraan antara laki-laki dan perempuan serta ketidakadilan terhadap perempuan adalah akibat dari pembacaan literal terhadap al-Qur'an. Dalam konteks ini kemudian ia yakin, agar terjadi kesetaraan dan keadilan gender, diperlukan pembacaan atas al-Qur'an yang kontekstual, bukan literal-tekstual (Nurmila, 2009: 12, 149-150).

Senada dengan Nurmila, sebelumnya Nasaruddin Umar pernah mengatakan bahwa memang ada produk-produk penafsiran yang bias jender dalam kitab-kitab tafsir. Ia juga mensinyalir adanya metodologi tafsir yang mengarah pada bias jender. Metode taḅliti misalnya, menurutnya cenderung bersifat parsial (sepotong-sepotong) dalam menangkap weltanchamung al-Qur'an, sehingga hasil penggunaan metode ini menjadikan penafsiran tidak utuh. Termasuk di dalamnya ketika berbicara tentang poligami. Metode tạ̣liti, menurutnya terkesan 
mempermudah untuk mengizinkan seseorang berpoligami jika dapat memenuhi syarat adil. Berbeda dengan metode maudhüīyang melihat al-Qur'an secara integral-komprehensif. Metode yang terakhir ini menangkap ada ayat lain yang memustahilkan syarat adil untuk dapat dilakukan manusia. Singkatnya, hasil kedua metode ini cenderung berbeda (Umar, 1999: 282-283).

Berdasarkan pada beberapa faktor di atas, penulis menganggap perlu untuk melihat tawaran-tawaran metodologi tafsir dan penafsiran alternatif terkait isu-isu bias jender tersebut, terutama terkait isu poligami. Tokoh Abu Zayd penulis kira menarik untuk diangkat, terlepas dari kontroversi yang melingkupi dirinya, karena pertama, ia cukup akrab dengan bidang tafsir al-Qur'an, kedua, ia juga pernah menulis karya terkait perempuan, dan yang lebih menarik lagi ketiga, ia sendiri mengatakan bahwa ia adalah seorang feminis-tepatnya feminis Muslim (Ichwan, 2003: xii).

Tulisan ini akan membahas pemikiran tafsir Nasr Abu Zayd (w. 2010) dan melihat penerapan metode tafsirnya ketika ia menjelaskan "ayat-ayat poligami." Melalui kajian bibliografis (library research), tulisan ini ingin memotret cara kerja metode tafsir Abu Zayd dalam menyingkap signifikansi teks yang tersembunyi, yang dalam istilah Abu Zayd disebut al-masküt 'anh. Istilah terakhir ini menarik untuk diangkat, karena menurut penulis ini merupakan satu tawaran metodologis alternatif untuk memecahkan kebuntuan pemikiran tafsir, terkait bagaimana cara mempertemukan antara problem teks yang terbatas dengan kenyataan kontemporer yang terus berkembang.

Isu poligami sengaja penulis pilih karena menurut penulis, isu ini masih tetap hangat dan selalu relevan untuk diperbincangkan. Karena sifatnya yang sensitif dan keterkaitannya dengan prinsip keadilan, kesetaraan, dan hak asasi manusia (HAM), maka hingga saat ini banyak sarjana dan pemerhati yang masih tertarik untuk mengangkat isu poligami sebagai objek kajian. Bagi mereka, terutama dari kalangan aktifis perempuan, praktek poligami merupakan satu dari rangkaian sistem ketidakadilan, yang bersumber dari sistem masyarakat yang bias patriarkhi. Selain melakukan advokasi secara langsung ke lapangan, mereka juga mencoba melakukan reformasi terhadap sistem yang tidak adil tersebut dan pada tataran yang lebih filosofis-teologis mereka melakukan reinterpretasi terhadap al-Qur'an yang selama ini dipandang mengandung bias patriarkhi yang cenderung merugikan kaum perempuan (Mernissi \& Hasan, tt.: 40). 
ljtihad: Jurnal Wacana Hukum Islam dan Kemanusiaan, Volume 17, No. 2, Desember 2017: 155-174

\section{Nasr Abu Zayd: Profil dan Pemikiran Tafsirnya}

Nasr Hamid Abu Zayd dilahirkan pada 10 Juli 1943 di Mesir. Bidang keilmuannya (core study) sebenarnya adalah ilmu sastra Arab. Pendidikan akademisnya (B.A., M.A., dan Ph.D.) ia peroleh dari jurusan bahasa dan sastra Arab di Universitas Cairo, Mesir (1968-1981). Persentuhan Abu Zayd dengan kajian al-Qur'an untuk pertama kalinya yaitu ketika ia mengkaji teori majaz dalam al-Qur'an menurut Mu'tazilah, yang kemudian menjadi tesis masternya dengan judul al-Ittijăh al-'Aq $\bar{l} \bar{f} \bar{i}$ al-Tafsir: Dirasah $\bar{f} \bar{i}$ Qadiyyat al-Majā $\bar{f} \bar{i}$ al-Qur'an inda alMu'tazilah (1977). Pergulatannya dengan kajian al-Qur'an berlanjut ketika ia menulis disertasi untuk program doktoralnya dengan judul Falsafah al-Ta'wīi: Diräah fi Ta'wīl al-Qur'an Inda Mubyi al-Dïn ibn 'Arabi (1981).

Dari sejarah perjalanan intelektualnya, terekam bahwa Abu Zayd pernah menjadi fellow pada the Centre for Middle East Studies, the University of Pensylvania, Philadelphia, Amerika Serikat (1978), dan menjadi visiting professor di Osaka University of Foreign Studies, Jepang (1985-1989). Dari penjelajahan intelektualnya yang pertama itulah ia mengenal teori-teori hermeneutika modern. Bahkan setelah kembali ke Mesir, ia sempat menulis sebuah artikel tentang hermeneutika (sebuah review atas pemikiran F. Schleiermacher, W. Dilthey, Gadamer, Paul Ricoeur, dan ED. Hirsh). Sedangkan dari perjalanannya yang kedua, ia memiliki banyak waktu untuk menulis. Di antara karyanya pada periode ini adalah karya monumentalnya Naqd al-Khimāb al-Dīnì dan Mafhüm al-Nașs: Diräsah fì 'Ulüm al-Qur'ān (Rahman, 2001: 3 dan 12).

Di akhir karir intelektualnya, tepatnya pada masa pengasingannya di Belanda, Abu Zayd diangkat menjadi professor di Universitas Leiden dan Ibn Rushd chair of humanism and Islam di Universitas Utrecht, Belanda (1995-2010).

Di antara karya-karya Abu Zayd adalah al-Imam al-Shafi'i wa Ta'sis al-Aydiyülüizyyah wa al-

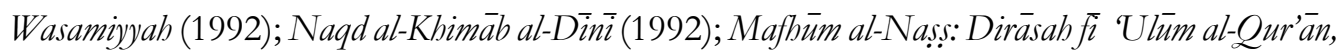
(1993); al-Naș wa al-Sulmah wa al-Haqiqqah: al-Fikerat al-Dïni bayna al-Irädah al-Ma'rifah wa Irädah al-Haymanah (1995), al-Mar'ah fi al-Khimāb al-Azma (1995), Dawā'ir al-Khauf (1999), alTafkir $\bar{f}$ Zaman al-Takefir (2003); Rethinking the Qur'an: Towards a Humanistic Hermeneutics, (2004); Voice of an Exile: Reflections on Islam (2004), dan Reformation of Islamic Thought: a Critical Historical Analysis (2006) (Ichwan, 1999: 11-20 dan 115-8). 
Nacr Abu Zayd adalah salah seorang sarjana Muslim yang mengarahkan penafsirannya untuk melahirkan tafsir al-Qur'an baru yang menekankan signifikansi dan relevansi teks bagi audien kontemporer-dalam istilah Abu Zayd, pembacaan produktif (al-qiräáah al-muntijah) atas al-Qur'an (Zayd, 1992: 115). Metode dan proses penafsirannya tidak berhenti pada makna literal teks, tetapi lebih jauh yaitu dengan berusaha menemukan tujuan akhir dari pewahyuannya.

Dia adalah di antara sedikit sarjana Muslim yang cukup akrab dengan dan telah menerapkan hermeneutika modern sebagai alat untuk menafsirkan al-Qur'an (Essack, 2007: 123). Dia melihat bahwa hermeneutika mirip dengan ta'wīl dalam istilah Arab. Keduanya, menurut Zayd, memiliki kesamaan makna dalam hal keduanya mencoba kembali kepada maksud asal teks (Zayd, 1993: 259-260). Bagi Abu Zayd, penggunaan hermeneutika modern atas alQur'an ini didasarkan pada pandangannya tentang tekstualitas al-Qur'an.

Menurut Abu Zayd, tekstualitas al-Qur'an tampak di dalam al-Qur'an sendiri. Al-Qur'an adalah Kalam Allah (kalām Allăh) dan Risalah-Nya (risālab). Sebagai kata-kata dan pesan, alQur'an adalah mungkin untuk dikaji sebagai teks. Ia berpendapat bahwa untuk memahami al-Qur'an dengan tepat, maka teks al-Qur'an tersebut harus diletakkan sebagai teks historis

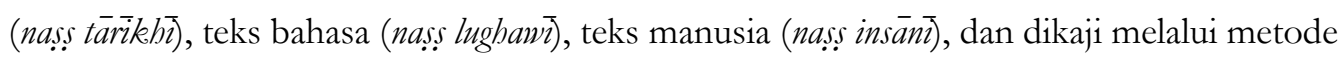
linguistik (manhaj al-lughawī) (Sukidi, 2009: 184-185). Lagi pula, menurutnya, urutan tekstual ayat-ayat dan surat dalam al-Qur'an itu berbeda dari urutan kronologis pewahyuan. Apabila urutan kronologis wahyu menunjukkan historisitasnya, sementara urutan strukturalnya seperti tertulis di dalam al-Qur'an sekarang ini adalah mencerminkan tekstualitasnya. Lebih jauh, Zayd berpendapat bahwa al-Qur'an selayaknya dipahami melalui tekstualitasnya dan bahwa pemahaman yang komprehensif atas tekstualitas teks al-Qur'an ini akan mengarah pada pemahaman atas pesan-pesan al-Qur'an (Ichwan, 1999: 54-55).

Menurut Abu Zayd, untuk memahami teks al-Qur'an dengan tepat, seseorang tentu harus mengetahui bahasa Arab, karena teks al-Qur'an diturunkan dan ditulis dalam bahasa Arab. Menurut Abu Zayd, pertama-tama, seorang penafsir harus mengetahui ilmu-ilmu seperti morfologi, semiotik, dan semantik. Setelah itu ia harus memahami ilmu nạ̣wu, i'rāb,

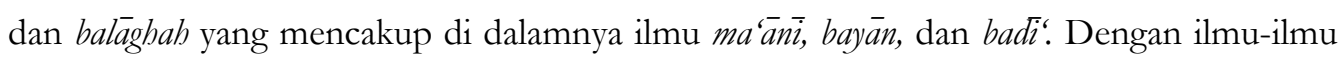
ini, seorang peafsir akan mampu menyingkap makna dari teks (Zayd, 1993: 268). 
Di samping itu, karena teks al-Qur'an telah mengubah makna beberapa istilah-istilah bahasa Arab Pra-Islam, seperti salat, zakēt, dan caum, dan memberi makna baru terhadap istilah-istilah tersebut dengan makna khusus keagamaan (al-dalälah al-shar'iyyah), maka seseorang harus mengetahui perubahan evolusional makna istilah-istilah semacam itu dengan mempelajari kesejarahannya (Zayd, 1995: 314-315). Seperti Fazlur Rahman dan para kontekstualis lain, Abu Zayd menyarankan bahwa seorang penafsir seharusnya memahami makna historis alQur'an (al-dalälah al-tärikhiyyah) sebagai makna asli teks dengan mengkaji konteks sosiohistoris dan kultural dari audien pertama al-Qur'an (Abu Zayd, 1995: 239).

Teori kontekstual Abu Zayd terletak pada dua level: pertama, konteks al-Qur'an sendiri pada saat diturunkan, yang mencakup pada konteks internal dan eksternal; dan kedua, konteks masa di mana signifikan teks akan diterapkan. Menurut Abu Zayd, sebuah penafsiran kontekstual (al-qirāah al-siyāqiyyah) harus mengikuti dua langkah ini, yaitu, pertama, kembali pada makna dalam konteks historis dan kultural teks (tärikhiyyat al-dalälab); dan kedua, menerapkan makna signifikansi (maghzā) dalam konteks kontemporer/kini (Rahman, 2001: 155-156).

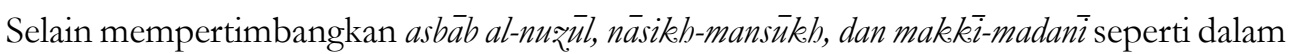
ilmu ushul fiqh, untuk menemukan makna kontekstual teks, menurut Abu Zayd, seorang penafsir harus mengkaji teks dalam konteks sosio-historis (al-siyāq al-tarikehi al-ijtima $\bar{\imath} \bar{\imath}$ bangsa Arab abad ke tujuh Masehi, yaitu pada saat al-Qur'an diturunkan. Inilah yang Abu Zayd sebut dengan konteks eksternal teks (al-siyāq al-kharijīi).

Pengetahuan terhadap konteks eksternal ini sangat penting. Dengan mengetahui konteks ini, seorang penafsir akan mengetahui apakah kandungan hukum dan aturan dari makna teks tersebut secara original ditetapkan Islam atau berasal dari adat kebiasaan yang sudah ada sebelum Islam yang kemudian diterima dan dikembangkan Islam. Selain dari itu, menurut Abu Zayd, terkait hubungan teks dengan dunia di sekitarnya ini, konteks khitab teks (siyāq altakhämub) atau konteks al-Qur'an ketika ia diturunkan (siyāq al-tan₹īi), termasuk di dalamnya sisi pengirim dan penerima, harus juga diperhatikan.

Adapun konteks internal (al-siyäq al-dakbijī) teks, mencakup di dalamnya urutan kronologis turunnya teks (tartīb al-nuzūi), konteks penyajian (siyāq al-sard), dan struktur linguistik teks (tarkīib al-lughaw $\bar{\imath}$. Pengkajian linguistik ini menurut Abu Zayd, bukan hanya dapat digunakan 
untuk memahami makna struktur teks, tetapi juga akan menyingkap makna yang tidak disebutkan (al-masküt 'anb) dari teks. Makna yang terakhir ini menurutnya dalah makna di balik strtuktur (Rahman, 2001: 158).

Dengan mempertimbangkan hal-hal di atas, seseorang akan menemukan makna asal ( ma'nā) dari teks al-Qur'an dan tujuannya (al-ghāyah). Istilah yang kedua ini dalam hermeneutika disebut dengan signifikansi (significance). Terkait teori significance ini, menurut Abu Zayd, jika makna asal (ma'nāa itu tidak berubah, maka significance (maghzāa ini bisa berubah (changeable) dan berbeda (different) sesuai dengan perbedaan konteks (ruang dan waktu). Dan seorang penafsir harus menyingkap signifikansi dari teks tersebut untuk konteks sekarang (Zayd, 1992: 114).

Dalam proses menafsirkan al-Qur’ān, Abu Zayd mengusulkan kepada penafsir (mufassir) untuk menemukan makna tersembunyi dari teks (al-mask $\bar{u}$ ' $a n h)$ dengan mulai membacanya dan diikuti dengan pembacaan analitis (al-qiräa ah al-taḅliliyah), melalui mana kunci dan ide-ide utama dari teks akan mungkin ditemukan. Inti-inti dan ide-ide dasar yang didapat itu, kemudian digunakan untuk menyingkap makna-maksa tersembunyi lain dan mengembangkan pembacaan-pembacaan baru. Pembacaan interpretatif ini harus didasarkan pada keterlibatan total pembaca dalam dunia teks. Abu Zayd yakin bahwa kesadaran akan perbedaaan antara makna asli secara kontekstual dan signifikansinya akan menghasilkan penafsiran yang lebih valid (Ichwan, 1999: 68-9).

\section{Poligami dalam perdebatan}

Poligami adalah salah satu isu yang paling hangat diperdebatkan dalam Islam. Praktek beristri lebih dari satu ini senantiasa menjadi bahan perbincangan, baik oleh kalangan Muslim sendiri maupun pihak non-Muslim (Hoffman, 1987: 23-50; McDonough, 1987: 2-3; Stowwaser, 1994; Freyyer, 1997: 67-104; Freyyer, 1998: 30-44), karena sensitifitasnya terutama terkait kesetaraan jender dan hak asasi manusia. Banyak kalangan menolak praktek poligami dengan berbagai alasan, seperti HAM, politik, sosial, kesehatan, dan lain-lain. Poligami dianggap bertentangan dengan norma-norma progresif dunia.

Mereka yang gandrung mengkaji isu poligami dari kalangan Muslim tersebut adalah terutama mereka dari kalangan aktifis perempuan dan feminis Islam. Untuk menyebutkan 
nama, di antaranya: Riffat Hasan, Fatima Mernissi, Asma Barlas, dan Amina Wadud. Mereka melihat ada ketimpangan dan ketidak-adilan yang dihasilkan oleh suatu tatanan sosial yang patriarkhal dan karena itu mereka mencoba mendekonstruksi sekaligus merekonstruksi wacana tafsir yang dipandang bias patriarkhi tersebut (Mustaqim, 2002: 67). Dari kalangan non-Muslim (Islamisis), sebut misalnya: Hoffman, Sheila McDonough, Barbara Freyyer Stowwaser, AHM. Zahniser, Yvonne Yazbeck Haddad, dan John L. Esposito.

Memang faktanya Islam tidak melarang poligami. Tapi tidak benar kalau dikatakan bahwa Islam adalah institusi yang pertama kali mempraktekannya, seperti dituduhkan banyak sarjana Barat. Poligami sejatinya adalah praktek kuno yang ditemukan di banyak masyarakat, bahkan sebelum Islam. Poligami kini memang banyak dipraktekkan di negera-negara berpenduduk Muslim, selain di belahan Afrika. Praktek poligami ini diakui secara legal di Chad, Kongo, Gabon, Jambia, Mali, Mauritania, Nigeria, Sierra Leone, Sudan, Tanzania, Togo, Uganda, dan Zambia. Tetapi, di era modern, praktek poligami ini mulai dipertebatkan. Penolakan atas praktek ini terutama datang dari kelompok-kelopok perempuan dan organisasi-organisasi HAM yang melihat efek negatif dari praktek poligami terhadap perempuan dan anak.

Sebagai bukti dari adanya perdebatan tentang poligami ini di era kontemporer, kita bisa dengan mudah menemukan diskusi-diskusi dan tulisan-tulisan terkait hal itu. Pada tahun 2005, ada sebuah konferensi dunia mengenai poligami dan syariah yang digelar di Kanada. Konferensi tersebut memperbincangkan soal titik temu antara iman (faith) dan hukum keluarga (family law). Di Inggris, ada perdebatan menyangkut kebijakan hukum Inggris terkait poligami (Shah, 2003). Di Amerika, pernah dilakukan sebuah riset terkait efek samping dari poligami di antara kaum perempuan Muslim Amerika dan kemudian riset tersebut menghasilkan sebuah kesimpulan bahwa ada penyalahgunaan (abuse) dalam praktek poligami tersebut. Untuk kasus di Indonesia, perdebatan tentang pro-kontra atas poligami ini dapat dibaca dalam buku Nina Nurmila Women, Islam and Everyday Life: Renegosiating Polygamy in Indonesia (Oxon: Routledge, 2009).

Berdasarkan pada hasil observasi mereka, di samping sisi positifnya, mereka berkesimpulan bahwa poligami mengakibatkan hal-hal yang negatif bukan hanya pada perempuan dan anak-anak secara personal, tetapi juga pada stabilitas sosial dan politik secara umum. Mereka berpendapat bahwa adalah sulit dan mungkin tidak mungkin bagi masyarakat yang mempraktekkan poligami untuk menjadi masyarakat yang terbuka dan demokratik. 
Di sisi lain, kaum Muslim menegaskan bahwa Islam tidak memulai praktek poligami, tidak juga mendorong para pemeluknya untuk mempraktekkannya. Ia hanya boleh dalam Islam karena disebabkan oleh beberapa alasan. Kevin el-Karim dalam www.answeringislam.com, dengan judul Response to the Lies and Distortions of Christian Missionaries about the Position of Women in Islam, mengutip beberapa sarjana Muslim terkenal menjelaskan bahwa poligami dalam Islam itu hanya boleh (tetapi tidak dianjurkan dalam suasana normal), dan bisa menjadi solusi untuk situsi dan kondisi tertentu, seperti ketika terjadi peperangan atau jumlah perempuan jauh melampaui laki-laki. Seseorang yang mau menikahi dua atau lebih istri, harus bisa memperlakukan istri-istrinya secara sama dan adil dalam hal makanan, minuman, rumah, pakaian, biaya hidup, dan dalam hal pembagian waktu bersama mereka.

Senada dengan Kevin, Syed H. Akhtar mengatakan benar bahwa Islam mengizinkan seorang laki-laki untuk menikahi lebih dari satu istri dalam keadaan tertentu, tetapi tidak mendorong praktek ini. Sebaliknya, poligami “dilarang” dalam Islam. Dia mengatakan:

Islam permits polygamy as an alternative to situations, which may force a husband to immoral acts. A husband may be forced to seek a second wife in the following situations: 1). Inability of the wife to bear children and the couple choose not to seek divorce. 2). Prolonged debilitating illness of the wife, where she is unable to provide sexual satisfaction to her husband, or carry on her responsibilities in relation to the family. 3). Prolonged physical separation due to war, travel, etc.

(Islam mengizinkan poligami sebagai sebuah alternatif dalam situasi-situasi yang mendorong seorang suami untuk berbuat yang tidak baik (immoral). Seorang suami terpaksa dapat mengambil istri kedua karena situasi-situasi berikut ini: 1). Ketidakmampuan istri melahirkan anak, dan pasangan tersebut tidak ingin bercerai. 2). Istri mengalami sakit yang tak kunjung sembuh, di mana sang istri tidak mampu memberikan kepuasan seksual kepada suaminya atau tidak bisa menjalankan kewajibannya dalam keluarga. 3). Keterpisahan fisik yang lama karena perang, perjalanan, dan sebagainya).

Selain dari yang disebutkan tadi, orang yang pernah berbicara mengenai poligami adalah Esra Ata, seorang anggota yayasan Islam Colorado (Colorado Islamic Foundation). Senada dengan Syed Akhtar, dia mengatakan bahwa pertama-tama Islam bukanlah yang pertama kali mempraktekkan poligami dan tidak mendorong mempraktekkan poligami atau menganggapnya sebagai sesuatu yang ideal. Kedua, Islam mengizinkan poligami dengan beberapa batasan. Dia menjelaskan bahwa Islam membolehkannya dengan beberapa 
argumen, seperti berikut:

- Memperlakukan istri-istri secara adil terkait makanan, rumah, pakaian, biaya hidup, dan waktu bersama mereka.

- Ada tempat dan waktu di mana faktor-faktor sosial, moral, dan psikologis menuntut praktek poligami.

- dalam banyak masyarakat, perempuan melebihi jumlah laki-laki. Khususnya banyaknya laki-laki yang meninggal karena perang, rasio jenis kelamin tidak seimbang. Perempuan di banyak masyarakat menerima poligami sebagai penjagaan dari perbuatan-perbuatan tidak senonoh, kesengsaraan dan kesusahan. Contoh: di Jerman, setelah perang dunia II, jumlah perempuan 7.3 juta jiwa melebihi laki-laki.

- Poligami cukup jarang terjadi di masyarakat Muslim kontemporer.

- Poligami adalah solusi yang mungkin diambil bagi gejala penyakit sosial di dalam masyarakat modern. Sebagian orang berpendapat bahwa ia bisa menjadi alternatif yang potensial bagi terjadinya perceraian dan perselingkuhan.

Selain dari pendapat-pendapat yang moderat ini, kita juga menemukan tokoh-tokoh yang mendukung konsep poligami ini. Di antara mereka adalah penulis Polygamy in Islam, Abu Ameenah Bilal Phillips and Jameelah Jones (Phillips, 2005). Dalam buku ini, penulis menjawab pertanyaan kenapa Islam membolehkan kaum Muslim menikahi lebih dari satu istri. Mereka menjawabnya dengan beberapa justifikasi dan alasan. Mereka menjelaskan semua karakteristik yang terpenting dalam pernikahan dalam Islam dan menunjukkan bahwa pandangan Barat tentang kesetaraan jender dan hubungan cinta kasih pra-nikah adalah tidak perlu dalam pernikahan Islami yang didasarkan pada kesucian dan komitmen kedua belah pihak untuk mendapatkan kenikmatan dari Tuhan.

Bisa dikatakan bahwa pandangan kaum Muslim terkait poligami ini sangatlah beragam. Singkatnya, di antara mereka ada yang mendukung, ada yang menganggap praktek poligami sebagai suatu yang dibolehkan berdasarkan syarat-syarat tertentu, dan ada pula yang menolaknya dan mengatakan Islam secara implisit melarang poligami. Kelompok terakhir ini umumnya berasal dari kalangan yang disebut dengan Muslim liberal. Mereka berpandangan bahwa semangat dasar dan tujuan akhir dari pewahyuan adalah monogami. Pendapat 
semacam ini dapat ditemukan misalnya dalam pemikiran Fazlur Rahman (Rahman, 1979), Fatima Mernissi (Mernissi, 1995), Riffat Hasan (Hasan, 1990), Amina Wadud (Wadud dalam Kuzman, 1998), dan Nasr Abu Zayd. Sub bab berikut akan mencoba melihat pandangan dan pemikiran Abû Zayd tentang poligami.

\section{Pemikiran Nasr Abu Zayd tentang poligami}

Abu Zayd adalah seorang pemikir humanis. Pemikiran humanisnya tidak hanya tampak dalam memahami hakikat al-Qur'an (Zayd, 2004; Sukidi 2009), tetapi juga terlihat pada produk penafsirannya. Dari karya-karyanya terlihat bahwa ia sangat concern terhadap isu humanisme dan hak asasi manusia (HAM), termasuk di dalamnya adalah isu hak-hak perempuan dan kesetaraan gender. Dalam konteks ini, pembahasan tentang poligami mendapat prioritas yang proporsional.

Dari sekian banyak karyanya, ada dua buku Abu Zayd yang secara khusus membahas tentang perempuan, yaitu al-Mar'ah fi al-Khimāb al-Azmah (Perempuan di dalam Wacana Krisis, 1994), dan Dawä'ir al-Khauf: Qirā'ah fĭ Khimāb al-Mar'ah (Lingkaran Ketakutan: Pembacaan atas Wacana Perempuan, 1999). Buku yang terakhir ini sebenarnya adalah edisi baru dari buku yang pertama. Di dalam buku pertama, Abu Zayd mencoba menganalisa wacana keagamaan tentang perempuan dalam hubungannya dengan wacana kebangkitan (nahdah) Arab Islam. Dalam konteks ini, ia melihat seperti halnya "Barat-Eropa", kaum perempuan dipinggirkan dan dijauhkan dari segala bidang kehidupan masyarakat (Mesir). Sedangkan dalam buku yang kedua, Abu Zayd menambahkan beberapa bab, yang membahas ketakutan kaum laki-laki terhadap perempuan. Ketakutan kaum Adam ini, menurut Zayd bersumber dari kekuatan perempuan dalam hal toleransi dan kesabarannya, dan karena perempuan adalah “pembuat kehidupan” (șani' al-ḥay $\bar{a} \bar{t})$. Dari sinilah menurutnya, penindasan terhadap perempuan dalam berbagai bentuk dan dengan berbagai media terjadi. Di sini pulalah agama dipergunakan sebagai perangkat ideologis untuk menegakkan dominasi lakilaki (Zayd, 2003: xvii-xx).

Menurut Abu Zayd, salah satu tujuan (maqș̄̄d) yang diinginkan oleh al-Qur'an adalah kesetaraan antara laki-laki dan perempuan (Zayd, 1999: 207). Menurutnya, teks-teks terkait kesetaran ini tidak perlu dita'wilkan lagi. Terkait hal ini, Abu Zayd merujuk pada penjelasan 
al-Qur'an tentang posisi Adam dan Hawa ketika keduanya diturunkan ke bumi karena memakan buah terlarang. Menurut Abu Zayd, al-Qur'an dengan tegas menjelaskan bahwa keduanya bertanggungjawab atas perbuatan dosa tersebut dan oleh kerenanya keduanya patut untuk mendapatkan hukuman. Terkait dengan kedudukan yang sama antara laki-laki dan perempuan ini, Abu Zayd juga merujuk pada ayat yang menjelaskan bahwa keduanya tercipta dari satu jiwa (nafs wähidah) (QS. 4:1 dan 7:180), dan mereka juga memiliki kewajiban keagamaan, mendapat pahala dan siksa yang sama (QS. 3:195, 4:124, 7:71-72, dan 16:97) (Zayd, 1999: 207-209).

Dalam dua karyanya di atas, Abu Zayd juga membahas beberapa isu terkait status dan hak-hak perempuan, lalu kemudian mengkajinya dalam sinaran semangat dasar al-Qur'an, yaitu kesetaraan. Ia misalnya membahas tentang posisi perempuan yang tidak ada harganya sama sekali pada masa pra-Islam, kemudian al-Qur'an datang untuk meluruskan kekeliruan cara pandang tersebut. Terkait dengan asumsi bahwa Hawa tercipta dari tulang sulbi Adam, ia mengatakan bahwa hal itu tidak didasarkan pada al-Qur'an, tetapi didasarkan pada mitos, yang ditemukan pada banyak tafsir awal.

Terkait dengan ayat qiwām (QS. 4: 34):

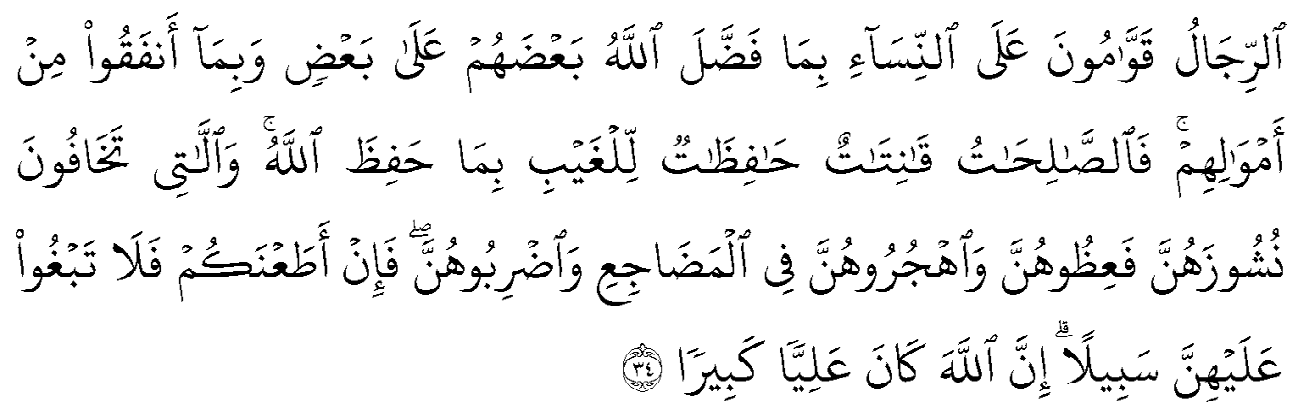

Abu Zayd mengatakan bahwa bunyi ayat ini harus dilihat sebagai sebuah penggambaran situasi dan bahwa pengutamaan laki-laki atas perempuan bukanlah keputusan mutlak Ilahi, tetapi merupakan sebuah pernyataan yang harus dirubah agar sesuai dengan tujuan asal diskursus al-Qur'an tentang perempuan. Kata qiwām secara linguistik juga terkait kemampuan untuk memberi nafkah, dan ini menurut Abu Zayd, kemampuan ini fleksibel bisa dilakukan oleh siapa saja, baik laki-laki atau perempuan, atau bisa juga oleh keduanya secara bersamasama (Zayd, 1999: 214). 
Dalam kitab Dawäir al-Khauf, Abu Zayd melakukan studi kritis atas wacana perempuan. Ia menolak pendapat beberapa kalangan yang cenderung merugikan perempuan, termasuk di dalamnya terkait isu poligami, seperti pendapat Muhammad al-lalibi dan kaum Salafi. Allalibi misalnya berpendapat bahwa poligami dapat dimaklumi karena dua hal: pertama, sejarah dominasi laki-laki atas perempuan dalam kepemimpinan, dan kedua, kesenjangan antara libido seksual laki-laki (yang tinggi) dan libido perempuan secara alami dari aspek biologis. Ia juga berpendapat bahwa walaupun poligami adalah hal yang asing, tetapi ia lebih baik dari pada perbuatan zina. Terhadap pendapat seperti ini Abu Zayd menyatakan bahwa pendapat semacam ini lebih merupakan justifikasi ketimbang penafsiran, karena penafsiran terhadap dominasi historis laki-laki atas perempuan harus bertitik tolak dari antropologi perkembangan ketimbang dari ilmu alam biologis. Pendekatan yang kedua ini menurutnya mengabaikan hakikat eksistensi manusia sebagai entitas kultural. Pendapat seperti itu hanyalah mempersempit eksistensi manusia dalam kerangka entitas biologis semata, yang tidak memiliki sejarah kecuali sejarah alam, dan memiliki kebudayaan yang terlepas dari kebudayaan lain. Pendapat yang mengatakan bahwa libido seksual laki-laki lebih tinggi dari perempuan, karena perempuan lebih banyak disibukkan dengan urusan reproduksi (kehamilan dan pembuahan sel telur) menurut Abu Zayd adalah pendapat yang tidak didukung oleh bukti ilmiah (Zayd, 1999: 228).

Kemudian Abu Zayd juga mengkritisi kaum literalis yang tidak setuju dengan kebijakan yang tertuang dalam Undang-Undang Keluarga Tunisia. Inti dari penolakan kaum literalis dan Salafi terhadap undang-undang tersebut adalah pertama, terkait pelarangan poligami, dan kedua, pemberian otoritas talak hukum pengadilan, bukan kepada suami. Mereka menolak dua hal ini dengan alasan bahwa hal tersebut "mengharamkan apa yang telah dihalalkan oleh Allah (yuḥarrimu mā ạ̣allallāh), yaitu boleh poligami berdasarkan QS. Al-Nisa: 3. Ini menurut mereka adalah bentuk penentangan terhadap penjelasan Allah.

Kritikan Abu Zayd juga tertuju pada kaum Salafi yang melihat persoalan poligami sebagai persoalan keimanan yang dekat dengan kategori sunnah yang wajib diikuti. Sebagian dari mereka melihat poligami sebagai bagian dari sunnah-sunnah yang dikhawatirkan akan sirna atau mati dan merupakan kewajiban seorang Muslim yang hakiki adalah menjaga dan menghidupkannya. Bahkan sebagian lain dengan berlebihan mengatakan bahwa poligami 
merupakan ujian untuk menilai keimanan perempuan/istri dan kekokohannya dengan menerimanya dan berbagi dengan perempuan kedua (mungkin juga ketiga dan keempat), yang dinikahi suaminya.

Terkait prinsip "tidak ada ijtihad di dalam persoalan yang sudah ada teksnya," yang dipegangi kaum Salafi, Abu Zayd mengkritisi dengan menunjukkan bukti sejarah di mana 'Umar ibn Khammâb mengabaikan hukum teks pada tahun paceklik dan tidak memotong tangan dua budak yang mencuri barang tuan mereka, tetapi malah mengancam akan menghukum sang tuan dengan potong tangan jika keduanya kembali mencuri. 'Umar melakukan hal ini walaupun ada teks (naṣṣ) dengan makna yang tegas (qam’i al-dalălah) (Zayd, 1999: 285-286).

Terkait QS. Al-Nisa: 3 yang menjadi sandaran kaum Salafi dan kelompok lain bagi kebolehan poligami, yang berbunyi:

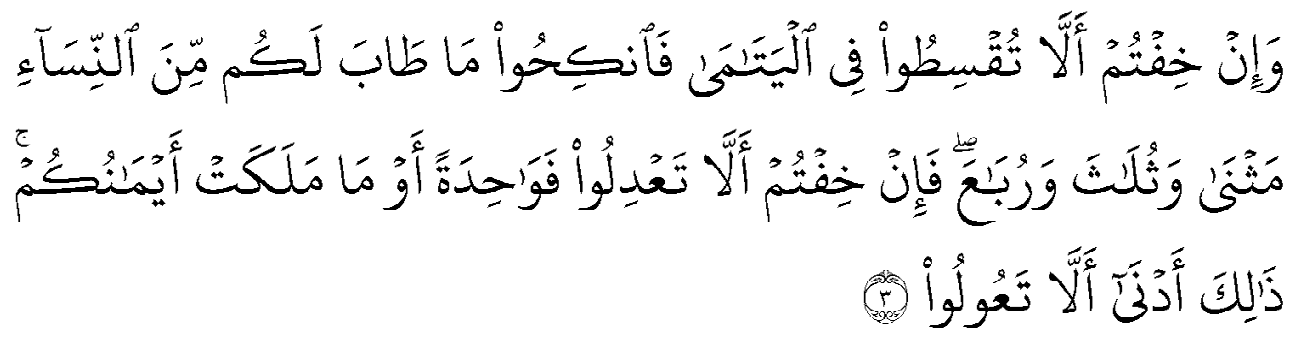

Artinya: "Dan jika kamu takut tidak akan dapat Berlaku adil terhadap (hak-hak) perempuan yang yatim (bilamana kamu mengawininya), Maka kawinilah wanita-wanita (lain) yang kamu senangi : dua, tiga atau empat. kemudian jika kamu takut tidak akan dapat Berlaku adil, ...

Abu Zayd melihat dan mengkritisinya dari beberapa hal, pertama Abu Zayd mempertanyakan kenapa para pengikut Salafi itu memegang teguh makna teks dengan mengabaikan makna: “atau budak-budak perempuan yang kamu miliki.” Kenapa kebolehan menggauli "budak perempuan yang dimiliki" itu diabaikan padahal hal tersebut ditetapkan oleh teks yang sama tingkat kejelasan dan ketegasannya. Maksud Abu Zayd dalam konteks ini adalah bahwa kaum Salafi tidak melihat bahwa "hilangnya" hukum menggauli budak perempuan ini diniscayakan oleh perjalanan kehidupan dan perkembangan realitas manusia melalui perjuangan manusia untuk mengembalikan kebebasan mereka yang telah didominasi 
oleh sebagian yang lain dalam konteks sistem ekonomi sosial kuno. Bagi Abu Zayd, dalam hal ini kaum Salafi menolak perjalanan dan perkembangan manusia, dan memilih hidup di luar sejarah (Zayd, 1999: 287).

Dalam konteks ini pula Abu Zayd ingin menunjukkan tentang adanya unsur historisitas dalam teks-teks keagamaan, yang merupakan teks-teks linguistik. Sedangkan menurutnya, bahasa merupakan produk sosial manusia dan lokus bagi kebudayaan bersama. Termasuk juga dalam hal ini adalah al-Qur'an yang menurutnya merupakan perbuatan yang menyejarah, yaitu suatu peristiwa yang terwujud dalam sejarah dan terkondisikan oleh akal objek pembicaraannya dan karakter realitas sosial serta budaya yang terwujud di dalamnya (Zayd, 1999: 287).

Kemudian Abu Zayd melihat ayat tersebut dalam konteks historisnya (secara eksternal). Dalam hal ini Abu Zayd mengatakan bahwa pembolehan poligami sampai jumlah empat istri harus dipahami dalam konteks karakter hubungan kemanusiaan (laki-laki dan perempuan) di dalam masyarakat Arab. Dalam konteks inilah ayat poligami dapat dipahami sebagai pembatasan dan secara historis merupakan transisi (naqlah) dalam rangka pembebasan perempuan dari ketergantungan laki-laki. Menurut Abu Zayd pembatasan nikah hanya dengan satu perempuan setelah rentang waktu selama lima belas abad dari perkembangan manusia dianggap sebagai transisi alamiah sesuai dengan jalan yang sudah dimulai oleh Islam (Zayd, 1999: 288).

Terkait konteks sosial pada saat ayat ini diturunkan, Abu Zayd juga mengatakan bahwa ayat tersebut diturunkan di Madinah setelah terjadi perang Uhud, di mana karena kejadian tersebut banyak sekali kaum laki-laki Muslim yang meninggal. Untuk menyikapi hal yang tidak diinginkan, di mana banyak sekali anak yatim dan janda-janda, maka al-Qur'an membolehkan untuk melakukan poligami (Zayd, 1999: 217).

Ia juga melihat fakta pada masa pra-Islam, poligami adalah satu hal yang biasa dipraktekkan di kalangan masyarakat Arab, bahkan sampai jumlah yang tidak terbatas. Dan al-Qur'an datang dengan membatasinya hanya empat istri dan dengan sejumlah ketentuan yang ketat. Di antara ketentuan tersebut adalah, pertama, harus ada keadaan yang membolehkan; dan kedua, seorang suami yang berpoligami harus dapat berbuat adil di atara istri-istrinya.

Selanjutnya, Abu Zayd juga melihat ayat tersebut dalam konteks al-Qur'an secara keseluruhan, Abu Zayd meyakini bahwa peletakan teks di dalam konteksnya yang lebih luas 
dapat mengungkap makna yang penting, yaitu dimensi yang tersembunyi (al-maskut 'anh) di dalam wacana. Bagi Abu Zayd, adanya ayat lanjutan yang berbunyi:

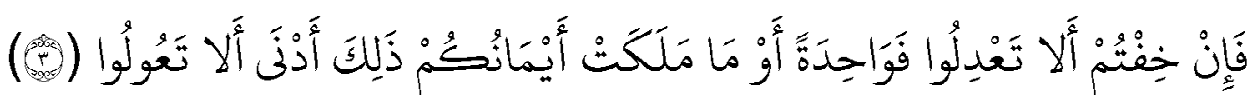

"Maka (kawinilah) seorang saja, atau budak-budak yang kamu miliki. yang demikian itu adalah lebih dekat kepada tidak berbuat aniaya.” (QS. Al-Nisa: 3)

menunjukkan bahwa bahwa perintah untuk mempraktekkan poligami tidak dimaksudkan sebagai aturan hukum permanen al-Qur'an, tetapi lebih merupakan sesuatu yang dibolehkan terkait syarat tertentu, terutama harus adanya sikap adil dari suami yang berpoligami tersebut.

Menurutnya, sesuai dengan konteks kebahasaannya, bentuk teks tersebut adalah bentuk syarat (sigah sharm) yang terkait antara kebolehan dan ketakutan tidak bisa berbuat adil terhadap anak-anak yatim. Sehingga sekali lagi perintah tersebut bukanlah perintah syara' yang tetap, tetapi dapat berubah sesuai dengan perubahan kondisi (Zayd, 1999: 217).

Akan tetapi adanya ayat lain, yaitu QS. Al-Nisa: 129, yang berbunyi:

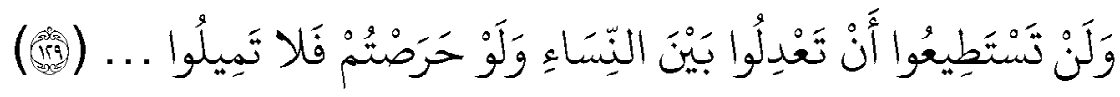

Artinya: "Dan kamu sekali-kali tidak akan dapat Berlaku adil di antara isteri-isteri(mu), walaupun kamu sangat ingin berbuat demikian, ...” (QS. Al-Nisa: 129).

menurut Abu Zayd menunjukkan kepastian sikap dan pembatalan poligami yang dipegangi oleh pengikut Salafi. Berdasarkan analisis linguistik, di mana struktur kalimatnya berupa kondisional (binā' al-jumlah al-syarmī dan menggunakan instrumen syarat (adät al-syarm) "lau", Abu Zayd mengatakan bahwa hal tersebut bermakna menghalangi terjadinya akibat (jawâb) karena keterhalangan terjadinya kondisi (syarm). Struktur (tarkijb) ini berarti bahwa keinginan untuk bisa berbuat adil tidak akan pernah terwujud, dan oleh karenanya terhalanglah terjadinya jawāb "berlaku adil" secara keseluruhan. Dan yang terpenting, adät nafy "lan" di awal kalimat bermakna penegasan, yaitu penegasan terjadinya suatu kejadian pada masa kini dan masa yang akan datang secara bersamaan. Selain itu, adanya jawāb al-syarm al-syarm yang negatif

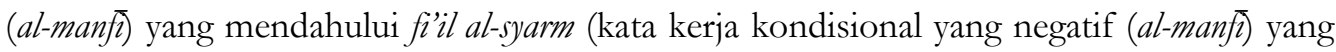
juga dengan adät "lau." Kondisi negatif ganda pada level makna ini bermakna penegasian 
abadi terhadap kemungkinan berlaku adil terhadap istri-istri, walaupun sangat menginginkannya (Zayd, 1999: 289).

Bagi Abu Zayd, "keadilan” adalah salah satu dari prinsip esensial dalam Islam. Maka jika ada pertentangan antara "prinsip" dengan hukum (pembolehan), maka suatu hukum tidak bisa naik ke level prinsip karena hukum adalah kejadian (hadas) parsial relatif yang dikondisikan oleh syaratsyarat yang bisa berubah-rubah karena adanya kebutuhan mendesak (darurah). Oleh karena itu, jika suatu hukum bertentangan dengan "prinsip" maka kita harus mengorbankan hukum itu. Dan oleh karenanya maka al-Qur'an-berdasarkan perkembangan konteks internal teks_-hampir mengharamkan poligami secara potensial (implisit [maskêut 'anł]) (Zayd, 1999: 289).

Berdasarkan pada ayat yang menyatakan bahwa seseorang tidak akan mungkin dapat berbuat adil walaupun ia menginginkannya tersebut juga, dan mengikuti Muhammad Abduh yang mendasarkan pendapatnya pada kaedah "mendahulukan menolak bahaya daripada mengambil manfaat" (dar al-mafasid muqaddam 'alā jalb al-masāilih), Abu Zayd berpandangan bahwa poligami dapat diharamkan secara tegas (muharam qam' $\imath$ ) apabila ada ketakutan tidak bisa berbuat adil (Zayd, 1999: 220-221).

Melalui analisis seperti ini, Abu Zayd menemukan makna (ma'na), arah teks (dalälah alnașs) dan signifikansi (maghza) teks. Dengan memperhatikan hal-hal tersebut tampaknya, ia berkesimpulan bahwa tujuan akhir dari pewahyuan (yang tidak tersurat [masküt 'anhu]) dari ayat-ayat poligami seperti tercantum dalam al-Qur'an adalah monogami (Ichwan, 2004: 37). Lebih tegas lagi, bisa dikatakan bahwa hukum praktek poligami, dalam pandangan Abû Zayd, bisa menjadi haram ketika ada ketakutan tidak bisa berbuat adil.

\section{Penutup}

Berdasarkan pembahasan di atas, terlihat bahwa Abu Zayd menggunakan metode tafsir tematik, dengan pendekatan kontekstual. Adapun teori penafsiran kontekstual (al-qiräab alsiyāqiyyah) Abu Zayd adalah sebagai berikut, pertama, kembali pada makna (ma'nāa dalam konteks historis dan kultural teks (tärikhiyyat al-dalälah); dan kedua, menerapkan makna signifikansi (maghzāa dalam konteks kontemporer.

Untuk mengetahui signifikansi (maghz $\bar{a})$, menurut Abu Zayd, seseorang harus mengetahui konteks, yang terdiri dari: konteks internal (al-siyāq al-dakbīīi) dan konteks eksternal (al-siyā 
al-kharijī). Konteks internal teks mencakup di dalamnya urutan kronologis turunnya teks

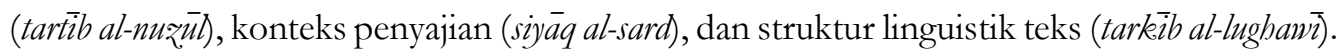
Adapun yang dimaksud dengan konteks eksternal adalah konteks sosio-historis (al-siya $\bar{q}$ altarikhi al-ijtimā' $\bar{\imath}$ bangsa Arab abad ke tujuh Masehi, yaitu masa pada saat al-Qur'an diturunkan. Termasuk konteks eksternal ini juga adalah konteks khitab teks (siyāq al-takhāmub) atau pengirim dan penerima pesan.

Dilihat dari corak dan alirannya, berbeda dengan tafsir-tafsir pra-modern yang bercorak dan beraliran fikih, kalam, filsafat, atau tasawuf, pemikiran Abu Zayd di bidang tafsir alQur'an adalah hermeneutis-lingusitik dan ijtima $\overline{-} \bar{i}$ (kemasyarakatan), sebuah corak dengan pendekatan teori interpretasi untuk aksi. Yang dimaksud dengan hermeneutis-linguistik di sini adalah bahwa Abu Zayd dalam proses penafsirannya selalu menggunakan teori-teori hermeneutika dan lingustik, termasuk juga khazanah sastra Arab. Sedangkan yang dimaksud dengan ijtima $\bar{a}, \bar{i}$ adalah bahwa Abu Zayd dalam usahanya menafsirkan al-Qur'an, selalu berorientasi pada kepentingan manusia (masyarakat).

Adapun dalam hal kecenderungan ideologis, walaupun Abu Zayd sendiri mengatakan bahwa metodologi tafsirnya diharapkan akan dapat menemukan makna objektif dan tidak idelogis (talwīn), tetapi dari pembahasan di atas terlihat bahwa Abu Zayd cenderung pada ideologi tertentu, seperti humanisme atau feminisme (khususnya terkait wacana perempuan).

Kemudian terkait poligami, menurut Abu Zayd poligami bukanlah tujuan akhir dari syariat Islam. Ia adalah ketetapan temporal yang terkait persyaratan-persyaratan yang sangat ketat. Berdasarkan pengkajian tematik dan hermeneutik-analitik-interpretatif, Abu Zayd berkesimpulan bahwa signifikansi teks al-Qur'an yang berbicara tentang poligami adalah keadilan dan kesetaraan. Dan pesan yang tersembungi (maskü' 'anh) dari struktur teks tersebut, yang merupakan tujuan akhir dari pewahyuan al-Qur'an adalah monogami. []

\section{Daftar pustaka}

Akhtar, Syed H. Islam the Misunderstood Religion in the West, dalam: http:/ /www.islamquery.com/ documents/Islam\%20the\%20Misunderstood\%20Religion.pdf.

Chapman, Samuel. polygamy, Bigamy and Human Rights law. USA: Xlibris Corporation, 2001. Essack, Farid. The Qur'an: A User's Guide, Oxford: Oneworld Publication, 2007.

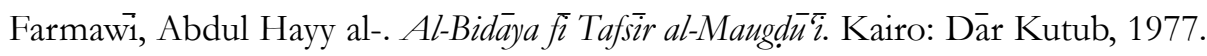


Freyyer, Barbara, "The Hijab: How Curtain Became an Institution and a Cultural Symbol," dalam Asma Asfaruddin dan AHM Zahniser. Indiana: Eisenbrauns, 1997. 67-104.

Freyyer, Barbara, "Gender Issues and Contemporary Qur'an Interpretation,” dalam Islam, Gender \& Social Change. Yvonne Yazbeck Haddad \& John L. Esposito, New York: Oxford University Press, 1998), 30-44.

Hanafi, Hasan. al-Yamīn wa al-Yasār fi al-Fiker al-Dinī, Mesir: Madlūbi, 1989.

Hasan, Riffat, “Feminisme dan al-Qur'an” dalam Jurnal Ulumul Qur'an Vol 2. 1990.

Hoffman, "Polemics on Modesty and Segregation of Women in Contemporary Egypt," International Journal of Middle East Studies 19, 1987.

Karim, Kevin el-. dalam: http://www.answering-islam.com/karim/part_3_o.pdf. Diakses pada Senin, 22 April 2013.

Kühn, Brittany, Universal Human Rights vs. Traditional Rights. dalam Topical Review Digest: Human Rights In Sub -Saharan Africa. dalam: http://www.du.edu/korbel/hrhw/ researchdigest/africa/UniversalHumanRights.pdf. Diakses pada Senin, 22 April 2013.

Ichwan, Moch Nur. A New Horizon in Qur'anic Hermeneutics: Nasr Hamid Abu Zayd's Contribution to Critical Qur'anic Scholarship. M.A. Thesis. Leiden: University, 1999.

McDonough, Sheila, "Modern Muslim Qur'an: Commentaries in relation to Gender Roles and Distinction," Religious Srudies and Theology. May-Sept 1987: p. 56-69.

Mernissi, Fatima dan Riffat Hasan. Setara di Hadapan Allab: Relasi Laki-laki dan Perempuan dalam Tradisi Islam Pasca Patriarkhi. Yogyakarta: Yayasan Prakarsa, 1995. , "Equal Before Allah.” dalam The Commite on South Asian Womens Bulletin, Vol. 4.

Mustaqim, Abdul. ed. Studi al-Qur'an Kontemporer (Wacana Baru Berbagai Metodologi Tafsir). Yogyakarta: Tiara Wacana Yogya, 2002.

Nurmila, Nina. Women, Islam and Everyday Life: Renegosiating Polygamy in Indonesia Oxon: Routledge, 2009.

Rahman, Fazlur. Islam. USA: University of Chicago Press, 1979.

Rahman, Yusuf. The Hermeneutical Theory of Nasr Hamid Abu Zayd. PhD Dissertation. Montreal: McGill University, 2001.

Rubin, Paul H. Democracy, Dictatorship, and Polygamy, dalam http:/ /www.cato.org/pubs/regulation/regv31n2/v31n2-noted.pdf. Diakses pada Senin, 22 April 2013.

Shah, Prakash. Attitudes to Polygamy in English law, University of Kent at Canterbury, 2003.

Sukidi. "Nasr Hamid Abu Zayd and the Quest for a Humanistic Hermeneutics of the Qur'an”, dalam Die Welt des Islams 49, 2009.

Stowwaser, Barbara Freyyer. Women in the Qur'an, Tradition and Interpretation. New York and Oxford: Oxford University Press, 1994. 
ljtihad: Jurnal Wacana Hukum Islam dan Kemanusiaan, Volume 17, No. 2, Desember 2017: 155-174

Umar, Nasaruddin. Argumen Kesetaraan Jender Perspektif al-Qur'an. Jakarta: Paramadina, 1999. Phillips, Abu Ameenah Bilal and Jameelah Jones. Polygamy in Islam, Riyadh: International Islamic Publishing House, 2005.

Phillips, Dena Hassouneh. Polygamy and Wife abuse: a Qualitative Study of Muslim Women in America. Health Care for Women International, Taylor \& Francis, 2001.

Wadud, Amina. "Qur'an and Woman," dalam Liberal Islam, Charles Kurzman, ed. New York: Oxford University Press, 1998.

Zayd, Abu. Dawā'ir al-Khauf. Kairo: Dār al-Nuṣūṣ, 1999. - al-Nașs wa al-Sultah wa al-ḥaqiqah: al-Fikera al-Dinī bayna al-Irädah al-Ma'rifah wa Irädah al-Haymana. Beirut: Al-Markaz al-Thaqū̄î̀ al-'Arabi, 1995.

Mafhüm al-Naș : Dirāsah fí Ulum al-Qur'an. Tt: al-Hayah al-Misriyyah al-Äma li alKitāb, 1993.

Naqd al-Khitāb al-Dïni. Kairo: Sina li al-Nashr, 1992.

. Rethinking the Qur'an: Towards a Humanistic Hermeneutics. Utrecht: Humanistic University Press, 2004.

Dekonstruksi Gender: Kritik Wacana Perempuan dalam Islam. terj. Moch Nur Ichwan, Yogyakarta: SAMHA, 2003. 